\title{
STREPTOMYCES AURANTICOLOR SP. NOV., A NEW ANTICOCCIDIAL ANTIBIOTICS PRODUCER
}

\author{
Hiroichi Ikushima, Eiko Iguchi, Masanobu Kohsaka, Hatsuo Aoki \\ and Hiroshi IMANAKA \\ Research Laboratories, Fujisawa Pharmaceutical Co., Ltd., Osaka, Japan
}

(Received for publication May 23, 1980)

\begin{abstract}
A new species of Streptomyces is described and designated Streptomyces auranticolor (FERM-P No. 5365) which produces new anticoccidial antibiotics, designated as WS-5995 A and WS- $5995 \mathrm{~B}^{1)}$. The organism is characterized by gray spore mass color, spiral spore chain with smooth spores, non-chromogenic reaction, soluble pigment, and carbon utilization characteristics. It differs from previously described streptomycetes on the basis of carbon utilization, and pigment production.
\end{abstract}

In the course of screening for new antibiotics, the interesting anticoccidial antibiotics, WS-5995 A and WS-5995 B, were discovered in a culture broth of strain No. 5995 which was recently isolated from a soil sample collected at Mt. Takao, Tokyo Prefecture, Japan. This report contains a description of this organism and a discussion of its taxonomic position.

\section{Materials and Methods}

The organism was selected from a series of soil isolations that were plated at dilutions of $1: 10^{2}$ to 1: $10^{4}$ on media for isolation.

The methods and media recommended by the International Streptomyces Project (ISP) ${ }^{2)}$ were used primarily, along with several supplementary tests. All tests were carried out at $28^{\circ} \mathrm{C}$.

Microscopic observations were made on cultures that were grown for 7 21 days on sucrose-nitrate, glycerin-asparagine, starch-inorganic salts, yeast-malt extract and oatmeal agar media. Sporophore morphology was observed on undisturbed plate cultures and carbon shadowing technique was used to obtain electron micrograph.

Colony characteristics were observed on slant cultures after 7 and 21 days of incubation using 12 kinds of media. The formulas for BENNETT's, glucose-asparagine, sucrose-nitrate and nutrient agars are those described by WAKSMAN ${ }^{3)}$.

Temperature range for growth was determined on BENNETT's agar slants using a temperature gradient bio-autorecorder (Toyo Kagaku Sangyo Co. Ltd.). Gelatin liquefaction was examined at 21 days on a medium composed of $20 \%$ gelatin, $2 \%$ glucose and $0.5 \%$ peptone. The medium was refrigerated after incubation to detect liquefaction. Starch hydrolysis was observed by the starch-iodine reaction after incubation on starch-inorganic salts agar plates at $28^{\circ} \mathrm{C}$ for 7 days. Melanin production was determined on agar slants of tyrosine, peptone-yeast iron, and other organic media, especially tryptone-yeast extract broth. Carbon utilization tests were made according to the Pridham-Gottlieb method $^{2)}$.

The procedure of BECKER et al. ${ }^{4)}$ was used for preparation of cells and for the chromatographic detection of the isomers of diaminopimelic acid.

\section{Results}

Strain No. 5995 produces vegetative mycelium, which does not fragment into spores, and aerial mycelium, which later forms spore chains. After 10 days of incubation at $28^{\circ} \mathrm{C}$, the spore chains appear 
Table 1. Cultural characteristics of strain No. 5995.

\begin{tabular}{|c|c|}
\hline Medium & Characteristics \\
\hline Sucrose-nitrate agar & $\begin{array}{l}\text { AM: none } \\
\text { VG: pale yellow, small colonies } \\
\text { SP: pink }\end{array}$ \\
\hline Glucose-asparagine agar & $\begin{array}{l}\text { AM: light gray to slightly greenish, cottony } \\
\text { VG: pale yellowish brown, small colonies } \\
\text { SP: orange }\end{array}$ \\
\hline Glycerin-asparagine agar & $\begin{array}{l}\text { AM: light gray, powdery } \\
\text { VG: pale yellow to pale yellowish brown, wrinkled colonies } \\
\text { SP: pale orange }\end{array}$ \\
\hline Starch-inorganic salts agar & $\begin{array}{l}\text { AM: light gray, powdery to short cottony } \\
\text { VG: yellowish brown to olive gray, small colonies } \\
\text { SP: none }\end{array}$ \\
\hline Tyrosine agar & $\begin{array}{l}\text { AM: light gray to whitish gray, powdery to short cottony } \\
\text { VG: yellowish brown, wrinkled colonies } \\
\text { SP: reddish orange }\end{array}$ \\
\hline Nutrient agar & $\begin{array}{l}\text { AM: none } \\
\text { VG: colorless to pale yellow, small colonies } \\
\text { SP: none }\end{array}$ \\
\hline Yeast-malt extract agar & $\begin{array}{l}\text { AM: white to whitish gray, powdery } \\
\text { VG: pale yellow to pale yellowish brown, wrinkled colonies } \\
\text { SP: none }\end{array}$ \\
\hline Oatmeal agar & $\begin{array}{l}\text { AM: light gray to gray, powdery to short cottony } \\
\text { VG: colorless to pale yellow, small colonies } \\
\text { SP: dull orange }\end{array}$ \\
\hline Peptone-yeast iron agar & $\begin{array}{l}\text { AM: none } \\
\text { VG: colorless to cream, small colonies } \\
\text { SP: none }\end{array}$ \\
\hline BENNETt's agar & $\begin{array}{l}\text { AM: gray, powdery to short cottony } \\
\text { VG: pale yellowish brown, slightly wrinkled colonies } \\
\text { SP: dull reddish orange }\end{array}$ \\
\hline Glucose-peptone gelatin & $\begin{array}{l}\text { AM: none } \\
\text { VG: colorless to pale yellow, wrinkled colonies } \\
\text { SP: none }\end{array}$ \\
\hline Milk & $\begin{array}{l}\text { AM: none } \\
\text { VG: weak growth } \\
\text { SP: none }\end{array}$ \\
\hline
\end{tabular}

Symbols: AM, aerial mycelium. VG, vegetative growth. SP, soluble pigment.

spiral in form with $5 \sim 50$ spores per chain. The spore chain morphology is classified in the Spirales Section (Fig. 1). The spores are ellipsoidal to short cylindrical, averaging $0.5 \sim 1.1$ by $0.9 \sim 1.7 \mu \mathrm{m}$ in size. The spore surface is smooth (Fig. 2).

The cultural characteristics and physiological properties are shown in Tables 1 and 2, respectively. On most media, strain No. 5995 develops pale yellow to yellowish brown moderate vegetative growth and the aerial mycelium is powdery to short cottony and light gray. The reverse color of colonies is not $\mathrm{pH}$ sensitive. Melanoid pigment is not produced in tyrosine agar or peptone-yeast iron agar. An orange pigment is found in the medium in glycerin-asparagine agar, oatmeal agar and in certain other media. The 
Table 2. Physiological properties of strain No. 5995.

\begin{tabular}{|c|c|}
\hline Property observed & Characteristics \\
\hline $\begin{array}{l}\text { Temperature } \\
\text { requirement }\end{array}$ & $\begin{array}{l}\text { growth from } 15^{\circ} \mathrm{C} \text { to } 40^{\circ} \mathrm{C} \\
\text { good sporulation at } 28^{\circ} \mathrm{C}\end{array}$ \\
\hline Gelatin liquefaction & no liquefaction \\
\hline Action on milk & $\begin{array}{l}\text { no coagulation, } \\
\text { no peptonization }\end{array}$ \\
\hline Starch hydrolysis & hydrolyzed \\
\hline Melanin production & none \\
\hline Cell wall type & J (containing LL-DAP) \\
\hline Carbon utilization & \\
\hline L-Arabinose & + \\
\hline D-Xylose & \pm \\
\hline D-Glucose & + \\
\hline D-Fructose & + \\
\hline Sucrose & + \\
\hline Inositol & - \\
\hline L-Rhamnose & + \\
\hline Raffinose & \pm \\
\hline D-Mannitol & + \\
\hline Mannose & + \\
\hline Salicin & - \\
\hline Galactose & + \\
\hline Lactose & - \\
\hline Maltose & + \\
\hline Glycerin & + \\
\hline
\end{tabular}

Symbols: +, good utilization. \pm , doubtful utilization. -, no utilization.
Fig. 1. Spore chain morphology of strain No. 5995 grown on yeast-malt extract agar: optical micrograph $(\times 300)$.

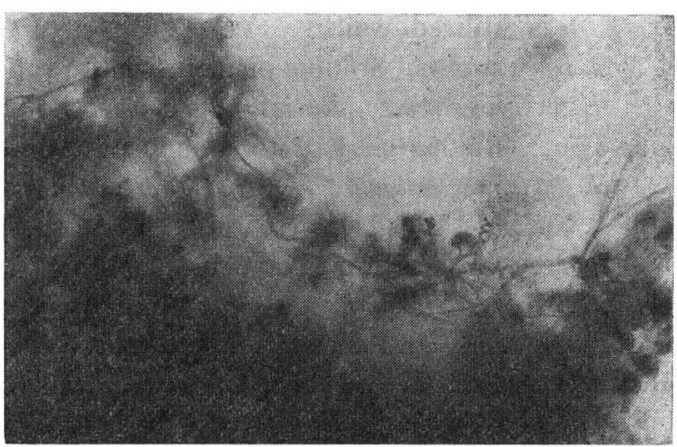

pigment is $\mathrm{pH}$ sensitive when tested with $0.05 \mathrm{~N}$ $\mathrm{NaOH}$ or $\mathrm{HCl}$. The orange pigment is changed to yellow by $0.05 \mathrm{~N} \mathrm{HCl}$, and to red by $0.05 \mathrm{~N}$ NaOH. Strain No. 5995 hydrolyzes starch well, but the hydrolytic activity is not detected on gelatin or milk. Inositol, salicin and lactose are not utilized for growth. Utilization of D-xylose and D-mannitol is doubtful and whole cell hydrolysates contain LL-diaminopimelic acid.

\section{Discussion}

Microscopic studies and cell wall type indicate that strain No. 5995 belongs to the genus Streptomyces. Accordingly, a comparison of the organism was made with those of Streptomyces species described in Bergey's Manual ${ }^{5)}$ and Nonomura's key for classification ${ }^{6)}$. From the abovementioned information, strain No. 5995 is considered to be closely related to Streptomyces minoensis,

Fig. 2. Spores of strain No. 5995 grown on yeast-malt extract agar: electron micrograph $(\times 9,000)$.

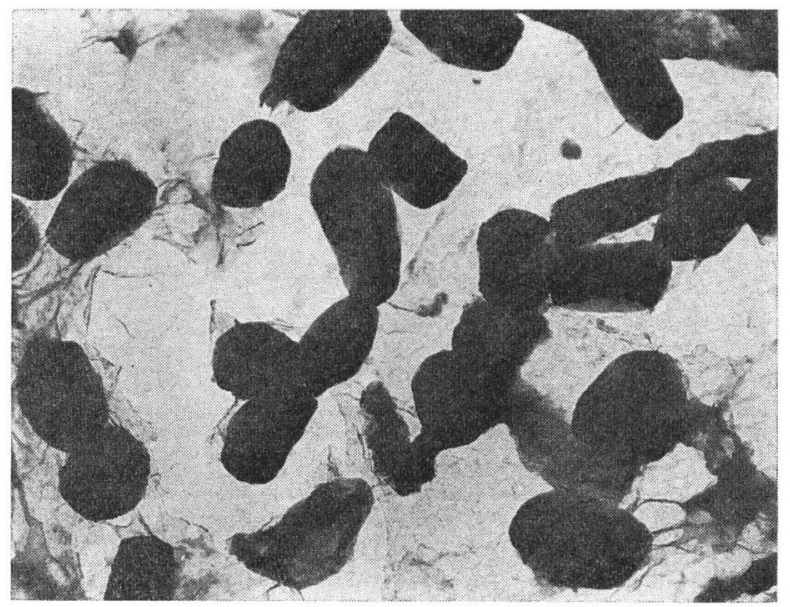


S. saraceticus, S. erythrogriseus, and S. griseoaurantiacus. The above species can be differentiated as follows:

S. minoensis: Aerial mycelium is often flexous to hooked. Soluble pigment is seldom produced. Inositol is utilized well.

S. saraceticus: Soluble pigment is not produced. L-Rhamnose is not utilized for growth.

S. erythrogriseus: Aerial mass color is not only gray, but also red and white on glycerin-asparagine agar. Neither sucrose nor raffinose is utilized. Inositol is utilized well.

S. griseoaurantiacus: Orange pigment in medium is changed to red by $0.05 \mathrm{~N} \mathrm{HCl}$, to brown by $0.05 \mathrm{~N} \mathrm{NaOH}$. Inositol is utilized well and sucrose is not.

On the basis of the above comparisons, strain No. 5995 is considered a new species of genus Streptomyces. Streptomyces auranticolor is proposed for strain No. 5995, referring to the distinctive orange pigment in medium. The type strain has been deposited in the Fermentation Research Institute, Agency of Industrial Science and Technology, Japan, as FERM-P No. 5365.

\section{References}

1) Ixushima, H.; M. Okamoto, H. Tanaka, O. Ohe, M. Kohsaka, H. Aoki \& H. Imanaka: New anticoccidial antibiotics, WS-5995 A and 5995 B. I. Isolation and characterization. J. Antibiotics 33: 1107 1113,1980

2) Shirling, E. B. \& D. Gottlieb: Methods for characterization of Streptomyces species. Int. J. Syst. Bacteriol. 16: 313 340, 1966

3) Waksman, S. A.: The Actinomycetes. Vol. 2. Classification, Identification and Descriptions of Genera and Species. The Williams and Wilkins Co., Baltimore, 1961

4) Becker, B.; M. P. Lechevalier, R. E. Gordon \& H. A. Lechevalier: Rapid differentiation between Nocardia and Streptomyces by paper chromatography of whole-cell hydrolysates. Appl. Microbiol. 12: $421 \sim 423,1964$

5) Pridham, T. G. \& H. D. Tresner: Bergey's Manual of Determinative Bacteriology, 8th ed., pp. 748 829, The Williams and Wilkins Co., Baltimore, 1974

6) Nonomura, H.: Key for classification and identification of 458 species of streptomycetes included in ISP. J. Ferment. Technol. 52: 78 92, 1974 